\title{
Passive Restoration of the Mountain Fens of the Caltho-Alnetum Community in the Babia Góra National Park
}

\begin{abstract}
Hydrogenic habitats play important ecological roles, particularly in mountain areas. In mountain areas, surface layers typically contain large concentrations of organic matter and are capable of accumulating large volumes of water. This has a positive impact on water management. Due to its specific properties, the soil in hydrogenic habitats supports many rare and often listed species of fauna and flora. Such hydrogenic habitats include: low sedge mountain fens and mountain fens of the Caltho-Alnetum community which, despite their limited areas, have a positive impact on biodiversity. In the $20^{\text {th }}$ century, drainage due to land use changes caused the degradation of many such habitats. As a result, soils from the organic matter accumulation phase entered the decay phase. A consequence of the change in habitat conditions is the extinction of many plant and animal species of narrow ecological amplitude, usually classified as stenotopic species. To prevent the degradation of hydrogenic habitats, it is necessary to start their restoration processes, which should be the most effective and possibly least intrusive. The work discusses both the methodology and restoration procedures of selected degraded habitats of mountain fen of the Caltho-Alnetum community in the Babia Góra National Park and presented the impact of those procedures on the water levels.
\end{abstract}

Keywords: restoration technique, hydrogenic habitat, drainage

Received: 27 February 2020; accepted: 16 March 2020

(C) 2020 Authors. This is an open access publication, which can be used, distributed and reproduced in any medium according to the Creative Commons CC-BY 4.0 License.

1 University of Agriculture in Krakow, Department of Soil Science and Agrophysics, Krakow, Poland, email: rrnicia@cyf-kr.edu.pl (corresponding author)

ORCID ID: https://orcid.org/0000-0002-6556-5868

2 West Pomeranian University of Technology in Szczecin, Department of Bioengineering, Szczecin, Poland, email: romualdabejger@wp.pl

ORCID ID: https://orcid.org/0000-0002-6924-4922

3 Museum and Institute of Zoology PAS, Warsaw, Poland, email: majka@miiz.waw.pl ORCID ID: https://orcid.org/0000-0001-9712-4285

4 University of Agriculture in Krakow, Department of Soil Science and Agrophysics, Krakow, Poland, email: rrzadroz@cyf-kr.edu.pl

ORCID ID: https://orcid.org/0000-0003-3736-2331 


\section{Introduction}

The degradation of hydrogenic habitats and related loss of biodiversity, changes of land use and increases in $\mathrm{CO}_{2}$ emissions have been known and broadly examined for some time [1-3]. The sustainable use of peatlands is difficult and should be facilitated by support schemes (e.g. for farmers) to promote their rational and extensive use [4]. Nowadays, a number of peatlands (used for agriculture or forestry in the previous century) are covered by various forms of nature conservation. Although attempts are also being made to restore those areas, the process can be difficult and costly [5,6]. Moreover, the restoration of biodiversity may also take a large amount of time $[7,8]$. The degradation of mountain hydrogenic habitats is not always the result of their drainage: it might be caused, for instance, by landslides due to agriculture-related erosion [9]. Provided the degradation of hydrogenic habitats is not advanced, and such habitats have not been drained by deep ditches, it is possible to improve them by applying simple restoration techniques.

The work discusses a restoration method of mountain fen habitats, but without removing the peaty-muck surface layer in selected degraded mountain fens of the Caltho-Alnetum community in the Babia Góra National Park.

\section{Materials and Methods}

\subsection{Study Area}

In Poland in the 1960s and 1970s, in a period of rapid economic growth, agriculture and forestry, many valuable habitats suffered degradation. In particular, the accelerated economic growth influenced hydrogenic habitats which were drained to acquire new land for agriculture and forestry. One such drained habitat were the mountain fens of the Caltho-Alnetum community. As prescribed by the 1957 Afforestation Guidance, the habitat was drained by ditches. The depth of ditches in the Caltho-Alnetum habitat varied from $0.3 \mathrm{~m}$ to $0.9 \mathrm{~m}$ [10]. In the area of the Babia Góra massif, to increase the drainage efficiency at Caltho-Alnetum plots, ditches were developed to drain water at its outflow. This was fairly easy, since the habitats were of a soligenic water supply type. The drainage of water directly from the place of its outlet from aquifers prevented water from spilling onto the habitat. Consequently, soils went from the organic matter accumulation phase to decession and, because of the lower groundwater level, their surface layers started to muck. Thus, the majority of Caltho-Alnetum habitats in Babia Góra have been degraded.

The mountain fens of the Caltho-Alnetum community within the Babia Góra massif are situated in the lower montane ecosystem on slopes with a maximum inclination of between 10-20\%. Their area is usually small, since patches of land occupied by the habitats rarely exceed several hundred square meters, whereas larger patches have $0.2-0.3$ ha. Soils of mountain fens of the Caltho-Alnetum community located in the Babia Góra National Park are characterized by very diverse properties [11]. 
In their surface layers, they may contain several to dozens of percent of organic carbon. The thickness of organic layers may vary from several centimetres to over $1 \mathrm{~m}$. The diversity of soil properties can also be seen between patches of the habitat and within one specific location as well. A large diversity of soil properties within one habitat is important when selecting locations for sampling. To be able to compare soil properties and their changes during the restoration process, it is necessary to conduct sampling at precisely the same location before and after the process.

The study covered six degraded mountain fens of the Caltho-Alnetum community in the Babia Góra National Park (Fig. 1). Three of them are unnamed fens and [12] the others are called: "Za Szałasem", "Pod Dolnym Płajem" and "Markowe Rówienki" [13]. The unnamed fens are situated on small patches of Caltho-Alnetum near the following fens: "Za Szałasem", "Pod Dolnym Płajem" and "Markowe Rówienki".

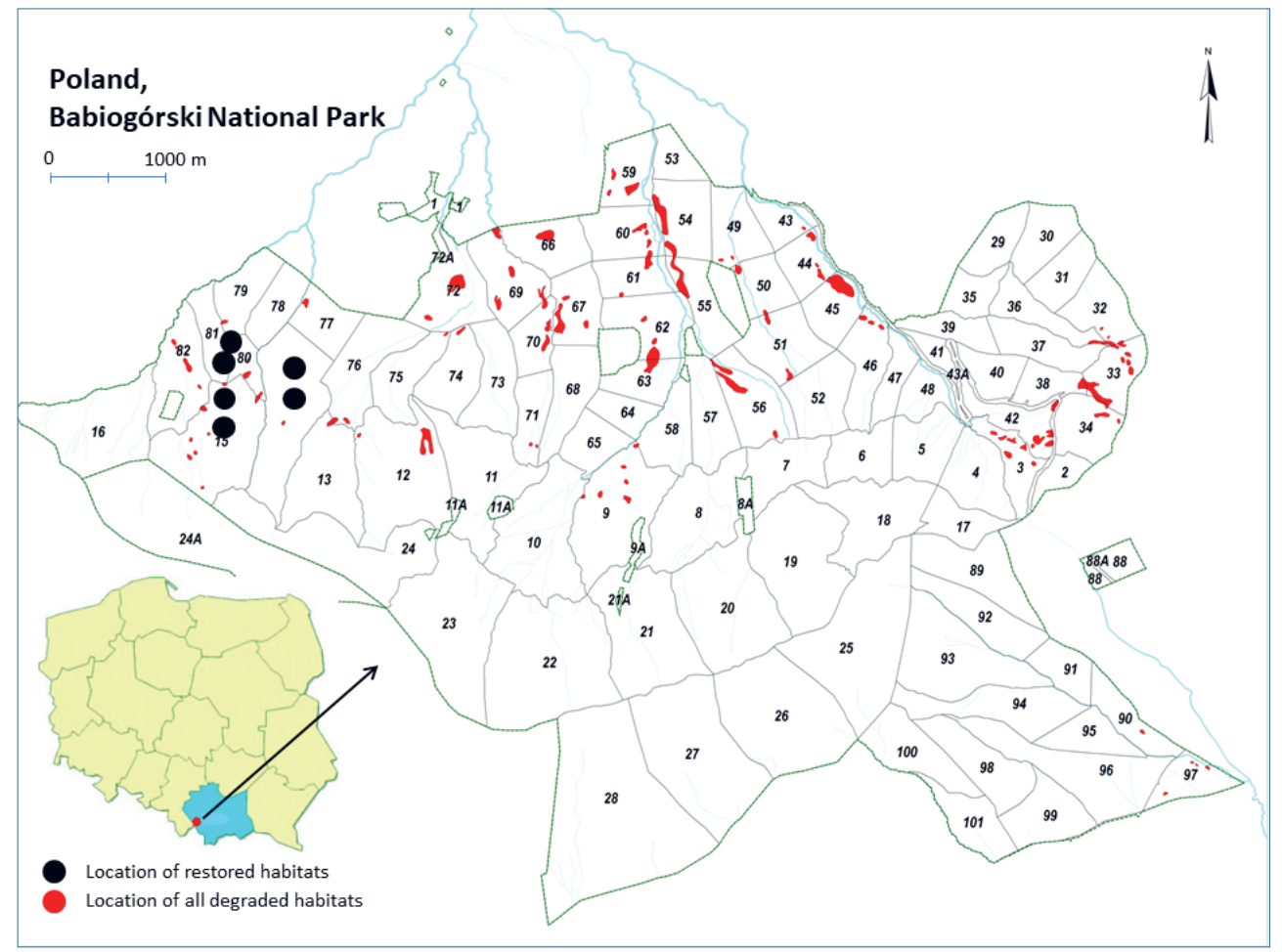

Fig. 1. Map location of degraded and restored habitats Source: database of the Babia Góra National Park

\subsection{Method of Restoration}

Peatlands in plains are typically restored by increasing their moisture level, removing the peaty-muck surface layer and the gradual increase of the groundwater 
level, removal of dominant flora, and reintroduction of stenotopic species, including the use of a seed bank [14]. The groundwater level is increased by placing locks in ditches within degraded habitats or by gradual backfilling or placing materials that slow the outflow of water in ditches [14, 15].

In mountain areas, restoration by removing the peaty-muck surface layer can be very difficult. In 2011, the survey of patches of degraded Caltho-Alnetum habitats in the Babia Góra National Park identified possible threats caused by the removal of the peaty-muck surface layer during restoration processes. In this case and with physiographic conditions existing in these areas, the use of this method would be difficult to realize and very risky. Degraded patches of habitats were situated in inaccessible areas, mostly slopes with inclination in excess of $10 \%$. According to the most popular methodology, the peaty-muck surface layer should be removed from the habitat, which would be impossible there. Mechanical removal of the peaty-muck surface layer could cause the degradation of other valuable natural habitats situated in the immediate vicinity of Caltho-Alnetum, e.g. Fagetum carpaticum Klika. After the removal of the peaty-muck surface layer, the danger of triggering soil erosion on the slopes was a separate issue. The risk was significant, since the removal of the topsoil eliminated other plants growing on those fens, and thus opened the area to surface runoff. Consequently, rainwater running down the slope could wash out organic layers of habitats right below the peaty-muck surface layer. We expected that the process could progress quite fast, since organic matter in Caltho-Alnetum habitats showed a high degree of humification $-\mathrm{H}_{8}-\mathrm{H}_{10}$ in the Von Post Scale [11]. During periods of heavy rain, the decomposed organic matter could degrade other habitats down the slope and contaminate water courses.

After analysing potential risks, in 2011, a decision was made to proceed with passive restoration. To increase the groundwater level within restored habitats, water runoff was gradually obstructed. Ditches were sealed to prevent the ingress of foreign materials into those valuable habitats. For this purpose, locally available dried wood, including plantings of 1960s and 1970s, was used. This included mostly trunks and branches of ash and spruce. Trunks and branches placed in ditches slowed down the flow of water and resulted in gradual silt accumulation. The method helped to avoid the introduction of foreign materials into the habitats and reduced the cost of the process.

\subsection{Measurement of Groundwater Levels}

Representative points were designated within the habitats and piezometers installed in each of them to measure the groundwater level. Piezometers were placed in different parts of the habitats, including in the vicinity of ditches. In 2018, five groundwater level measurements were made during the vegetation period. Groundwater level measurements continued after measurements performed in 2011-2013 [12] and 2011-2014 [13]. 


\section{Results and Discussion}

The hydrogenic habitats degradation, caused by their drainage, progresses very fast. Already after several weeks from the lowering of the groundwater level, soils of mountain fen under Caltho-Alnetum community, show changes in their structure. While drying, the dewatered amorphous organic mass shrinks and cracks which damages plant root systems (Fig. 2).

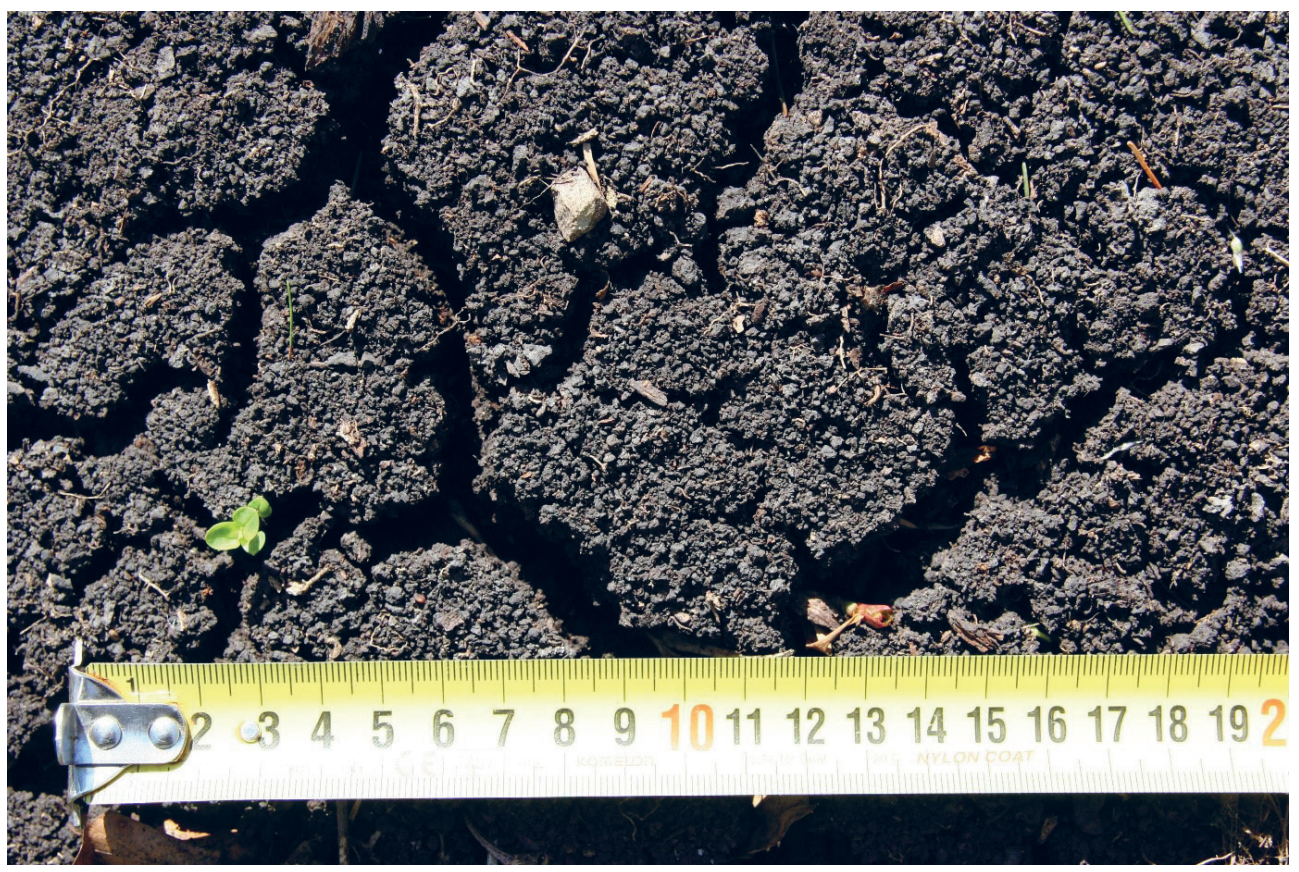

Fig. 2. Surface layer of studied fen several weeks into its drainage (photo P. Nicia)

The drop of the groundwater level changes physical and chemical properties of soil and water within the area [16, 17]. The processes lead to mineralization of drained organic matter and changes in the composition of stenotopic species of flora [12] and fauna [18] in the habitats.

Already after a few weeks, the restoration procedure applied to the Caltho-Alnetum habitat caused an increase in the groundwater level $[12,13]$. With the increase in the groundwater level, the species composition changed regarding the plants that occupied the habitat. The gradual increase in groundwater level continued until 2014. Three years after the starting of the restoration procedure, the continuous monitoring of groundwater level at the least degraded habitats ("Za Szałasem" fen drained with ditches of $0.15-0.30 \mathrm{~m}$ in depth) confirmed the restoration of a status which was close to the natural one. The 2013 groundwater level in the "Pod Dolnym 
Płajem" fen, where deeper ditches $(0.3-0.6 \mathrm{~m})$ were found, was also higher and reached the level approaching the natural one for Caltho-Alnetum habitats with an uninterrupted water balance. The degraded habitat of the "Markowe Rówienki" fen, drained with the deepest ditches, showed a weak reaction to restoration processes (Tab. 1).

Table 1. Groundwater level in restored habitats

\begin{tabular}{|c|c|c|c|c|}
\hline \multirow{2}{*}{ Fen name } & \multicolumn{4}{|c|}{$\begin{array}{l}\text { Groundwater level measured from topsoil surface } \\
\qquad[\mathrm{m}]\end{array}$} \\
\hline & $2011^{*}$ & $2013^{*}$ & $2014^{* *}$ & 2018 \\
\hline Za Szałasem & 0.150 & 0.050 & - & 0.050 \\
\hline Pod Dolnym Płajem & 0.350 & 0.080 & - & 0.070 \\
\hline Markowe Rówienki & 0.650 & 0.410 & - & 0.350 \\
\hline No-name fens & 0.265 & - & 0.092 & 0.080 \\
\hline
\end{tabular}

Source: *[13], **[12]

The unnamed fens also showed positive effects of restoration procedures applied with the 2014 level of groundwater increased by about $0.173 \mathrm{~m}$ compared to that of 2011 (Tab. 1).

After that period, no interventions were made into the system and the restoration process. Field surveys showed that trunks and branches placed in ditches significantly slowed the flow of water from the fens. Not only did trunks and branches play their role in the siltation process, but also Dentarioglandulosae-Fagetum leaves from trees surrounding the fens contributed considerably to the process. In autumn, leaves accumulated in ditches and reduced their water flow capacity. This, in time, led to the gradual siltation of ditches and water flowing out of fens was able to spill out into the degraded habitats.

The 2018 field survey proved that the restoration process was continuing. The 2018 groundwater level at the "Za Szałasem" fen did not change in relation to that of 2013 and remained at $0.05 \mathrm{~m}$. Such a level can be considered natural for the habitats [11]. Similar restoration effects have been found at the "Pod Dolnym Płajem" fen and patches of no-name fens, with their groundwater level increased close to the natural one.

The weakest restoration effects were recorded in the "Markowe Rówienki" fen. In 2018, the groundwater level there was $0.350 \mathrm{~m}$. The limited effects can be attributed to the fact that the fen was drained with the deepest ditches. Therefore, even after trunks and branches were placed in ditches, siltation was sluggish. To restore the natural groundwater level in the fen, it is necessary to continue its restoration processes by further controlled and gradual increases in the groundwater level. 


\section{Conclusions}

1. The restoration effect, measured by the level of groundwater, was visible in all studied fens. However, the restoration of natural habitat conditions may take several years.

2. The restoration of the Caltho-Alnetum habitats without the removal of the peaty-muck surface layer and with the use of natural materials is a fast and efficient method for the restoration of the natural status of habitats.

3. The decision as to the restoration method should be preceded by in-depth analyses of habitat conditions, including the analysis of physiographic conditions and the presence of other valuable natural habitats.

\section{References}

[1] Verones F., Saner D., Pfister S., Baisero D., Rondini C., Hellweg S.: Effects of Consumptive Water Use on Biodiversity in Wetlands of International Importance. Environmental Science \& Technology, vol. 47, issue 21, 2013, pp. 12248-12257. https://doi.org/10.1021/es403635j.

[2] Schulz Ch., Branas M.M., Nunez C., Aquila Villacorta M., Laurie N., Lawson I.T., Roucoux K.H: Uses, cultural significance, and management of peatlands in the Peruvian Amazon: Implications for conservation. Biological Conservation, vol. 235, July 2019, pp. 189-198. https://doi.org/10.1016/j.biocon.2019.04.005.

[3] Bullock C.H., Collier M.J., Convery C.: Peatlands, their economic value and priorities for their future management - The example of Ireland. Land Use Policy, vol. 29, issue 4, October 2012, pp. 921-928. https://doi.org/10.1016/j.landusepol.2012.01.010.

[4] Buschmann Ch., Röder N., Berglund K., Berlung Ö., Læke P.E., Maddison M., Mander Ü., Myllys M., Osterburg B., van den Akker J.J.H.: Perspectives on agriculturally used drained peat soils: Comparison of the socioeconomic and ecological business environments of six European regions. Land Use Policy, vol. 90, January 2020, 104181, pp. 1-13. https://doi.org/10.1016/j.landusepol.2019.104181.

[5] Quinty F., Rochefort L.: Peatland Restoration Guide. $2^{\text {nd }}$ ed. Canadian Sphagnum Peat Moss Association and New Brunswick Department of Natural Resources and Energy, Québec 2003.

[6] Price J., Heathwaite A., Baird A.: Hydrological processes in abandoned and restored peatlands: An overview of management approaches. Wetlands Ecology and Management, vol. 11, 2003, pp. 65-83. https://doi.org/10.1023/A:1022046409485.

[7] Komonen A., Grapputo A., Kaitala V., Kotiaho J.S., Paivinen J.: The role of niche breadth, resource availability and range position on the life history of butterflies. Oikos, vol. 105, 2004, pp. 41-54. 
[8] Spitzer K., Danks H.V.: Insect biodiversity of boreal peat bogs. Annual Review of Entolmology, vol. 51, 2006, pp. 137-161.

[9] Nicia P., Bejger R., Sterzyńska M., Zadrożny P., Parzych P., Bieda A., Kwartnik-Pruc A.: Recovery in soil cover and vegetation structure after ancient landslide in mountain fens under Caltho-Alnetum community and response of soil microarthropods (Hexapoda: Collembola) to natural restora tion process. Journal of Soils Sediments, vol. 20, 2020, no. 2, pp. 714-722. https://doi.org/10.1007/s11368019-02434-z.

[10] Nicia P., Zadrożny P., Lamorski T., Bejger R.: Właściwości gleb i wód młaki Krowiarki pod zbiorowiskiem roślinnym bagiennej olszyny górskiej (Caltho-Alnetum) w Babiogórskim Parku Narodowym. Woda-Środowisko-Obszary Wiejskie, t. 10, z. 1, 2010, pp. 123-132.

[11] Nicia P., Zadrożny P., Lamorski T.: General characteristic of selected soil profiles under the Caltho-Alnetum association in the Babiogorski National Park. Ecological Chemistry and Engineering A, vol. 16, no. 7, 2009, pp. 840-843.

[12] Nicia P., Bejger R., Sterzyńska M., Zadrożny P., Lamorski T., Stary J., Parzych P.: Restoration of hydroecological conditions in Carpathian forested mountain fens. Wetlands Ecology and Management, vol. 26, no. 4, 2018, pp. 537-546. https://doi.org/10.1007/s11273-017-9590-7.

[13] Nicia P., Bejger R., Zadrożny P., Sterzyńska M.: The impact of restoration processes on the selected soil properties and organic matter transformation of mountain fens under Caltho-Alnetum community in the Babiogórski National Park in Outer Flysch Carpathians, Poland. Journal of Soils and Sediments, vol. 18, no. 8, 2018, pp. 2770-2776. https://doi.org/10.1007/s11368-017-1909-8.

[14] Klimkowska A.: Rola glebowego banku nasion w renaturyzacji torfowisk na przykładzie Bagna Całowanie. Woda-Środowisko-Obszary Wiejskie, t. 6, z. 1, 2006, pp. 183-194.

[15] Rodney A.Ch., Cooper D.J., Bidwell M.D., Culpepper A., Zillich K., Nydick K.: A new method for restoring ditches in peatlands: ditch filling with fiber bales. Restoration Ecology, vol. 27, issue 1, 2019, pp. 63-69.

[16] Ilnicki P.: Torfowiska i torf. Wydawnictwo Akademii Rolniczej im. A. Cieszkowskiego, Poznań 2002.

[17] Nicia P., Miechówka A.: The effect of human activities and atmospheric conditions on ionic composition of low sedge mountain eutrophic fen waters. Polish Journal of Environmental Studies, vol. 16, no. 2A, part II, 2007, pp. 337-341.

[18] Sterzyńska M., Tajovsky K., Nicia P.: Contrasting responses of millipedes and terrestrial isopods to hydrologic regime changes in forested montane wetlands. European Journal of Soil Biology, vol. 68, 2015, pp. 33-41. https://doi. org/10.1016/j.ejsobi.2015.03.005. 


\section{Zastosowanie pasywnych zabiegów renaturyzacyjnych na siedliskach bagiennej olszyny górskiej Caltho-Alnetum w Babiogórskim Parku Narodowym}

Streszczenie: Siedliska hydrogeniczne pełnią ważne funkcje ekologiczne zwłaszcza na terenach górskich. Ich gleby charakteryzujące się dużą zawartością materii organicznej są w stanie akumulować znaczne ilości wody, co pozytywnie wpływa na gospodarkę wodną. Ze względu na specyficzne właściwości gleby tych siedlisk hydrogenicznych są miejscem występowania wielu rzadkich gatunków roślin i zwierząt, z których wiele jest objętych ochroną gatunkową. Do siedlisk hydrogenicznych należą m.in. młaki niskoturzycowe i bagienna olszyna górska, które pomimo małej powierzchni, jaką zajmują, na terenach górskich wpływają korzystnie na utrzymanie ich bioróżnorodności. W XX wieku wiele $\mathrm{z}$ tych siedlisk z powodu zmian sposobu użytkowania terenu zostało zdegradowanych $\mathrm{w}$ wyniku odwodnienia. Proces ten powoduje przejście gleb organicznych $\mathrm{z}$ fazy akumulacji $\mathrm{w}$ fazę decesji. Konsekwencją tego jest zmiana warunków siedliskowych oraz ekstynkcja wielu gatunków roślin i zwierząt o wąskiej amplitudzie ekologicznej zaliczanych do gatunków stenotopowych. Aby zahamować degradację siedlisk hydrogenicznych, konieczne jest podjęcie procesów renturyzacyjnych, których celem powinno być przywrócenie ich pierwotnych warunków. Procesy te powinny być jak najmniej inwazyjne w stosunku do terenów, na których znajdują się te siedliska te. W pracy omówiono metodykę oraz sposób przeprowadzenia procesów renaturyzacyjnych na wybranych, zdegradowanych siedliskach bagiennej olszyny górskiej w Babiogórskim Parku Narodowym oraz przedstawiono wpływ tych zabiegów na poziom wód mokradeł.

Słowa

kluczowe: techniki renaturyzacji, siedliska hydrogeniczne, odwodnienie 